\section{Kidney \\ Blood Pressure Research}

Kidney Blood Press Res 2013;37:567-578

DOI: $10.1159 / 000355737$
Published ontIne: November 30, 2013

Accepted: October 16, 2013

\title{
Sensitization of Erythrocytes to Suicidal Erythrocyte Death Following Water Deprivation
}

\author{
Majed Abed ${ }^{\mathrm{a}, \mathrm{b}} \quad$ Martina Feger $^{\mathrm{a}} \quad$ Kousi Alzoubi $^{\mathrm{a}}$ Tatsiana Pakladok \\ Leonie Frauenfeld ${ }^{a}$ Corinna Geiger ${ }^{a}$ Syeda T. Towhida Florian Langa \\ aDepartment of Physiology, University of Tuebingen, Tuebingen, Germany; ${ }^{b}$ Medicine Faculty, Al-Furat \\ University, Deir ez-Zor, Syria
}

Key Words

Eryptosis $\bullet$ Energy depletion $\bullet$ Hyperosmotic shock $\bullet$ Oxidative stress $\bullet$ Ionomycin

\begin{abstract}
Background/Aims: Klotho deficiency results in excessive formation of $1,25(\mathrm{OH})_{2} \mathrm{D}_{3^{\prime}}$ accelerated ageing and early death. Moreover, klotho deficiency enhances eryptosis, the suicidal erythrocyte death characterized by phosphatidylserine exposure at the erythrocyte surface. Triggers of eryptosis include increase of cytosolic Ca ${ }^{2+}$-activity $\left(\left[\mathrm{Ca}^{2+}\right]_{\mathrm{i}}\right)$, glucose depletion, hyperosmotic shock and oxidative stress. Klotho expression is decreased and $1,25(\mathrm{OH})_{2} \mathrm{D}_{3}-$ formation enhanced by dehydration. The present study thus explored whether dehydration influences eryptosis. Methods: Blood was drawn from hydrated or $36 \mathrm{~h}$ dehydrated mice. Plasma osmolarity was determined by vapour pressure method, plasma $1,25(\mathrm{OH})_{2} \mathrm{D}_{3}$ and aldosterone concentrations using ELISA, and plasma $\mathrm{Ca}^{2+}$-concentration utilizing photometry. Erythrocytes were exposed to $\mathrm{Ca}^{2+}$-ionophore ionomycin $(1 \mu \mathrm{M}, 30 \mathrm{~min})$, energy depletion (12 h glucose removal), hyperosmotic shock ( $500 \mathrm{mM}$ sucrose added, $2 \mathrm{~h}$ ) and oxidative stress (100 $\mu \mathrm{M}$ tert-butyl-hydroperoxide, $30 \mathrm{~min}$ ) and phosphatidylserine exposure at the erythrocyte surface estimated from annexin $\mathrm{V}$ binding. Results: Dehydration increased plasma osmolarity and plasma $1,25(\mathrm{OH})_{2} \mathrm{D}_{3}$ and aldosterone concentrations. Dehydration did not significantly modify phosphatidylserine-exposure of freshly drawn erythrocytes but significantly enhanced the increase of phosphatidylserine-exposure under control conditions and following treatment with ionomycin, glucose-deprivation, hyperosmolarity or tert-butyl-hydroperoxide. Conclusions: Dehydration sensitizes the erythrocytes to spontaneous eryptosis and to the triggering of eryptosis by excessive $\mathrm{Ca}^{2+}$-entry, energy depletion, hyperosmotic shock and oxidative stress.
\end{abstract}




\section{Kidney \\ Blood Pressure Research}

\begin{tabular}{l|l}
\hline Kidney Blood Press Res 2013;37:567-578 \\
\hline DOI: $10.1159 / 000355737$ & (c) 2013 S. Karger AG, Basel
\end{tabular}

Published online: November 30, 2013 www.karger.com/kbr

Abed et al.: Dehydration Induced Eryptosis

\section{Introduction}

Hydration sensitive genes [1] include klotho [2], a coreceptor of the FGF23 receptor contributing to downregulation of $1,25(\mathrm{OH})_{2} \mathrm{D}_{3}$ formation $[3,4]$. Mice with reduced klotho expression suffer from multiple age-related disorders with growth retardation, extensive soft tissue calcification and decreased life span paralleled by osteopenia/osteoporosis, endothelial dysfunction, impaired angiogenesis, sinoatrial node dysfunction with sudden cardiac arrest, pulmonary emphysema, skin atrophy, hypogonadotropic hypogonadism, infertility, muscle dystrophy, hearing loss, neuron degeneration, Parkinson's disease, cognition impairment, neoplasms, inflammation and tissue fibrosis [4-19]. Klotho deficiency is largely effective through excessive $1,25(\mathrm{OH})_{2} \mathrm{D}_{3}$ formation, stimulation of renal tubular phosphate transport and subsequent elevation of serum phosphate levels [20-22].

Klotho deficiency triggers eryptosis, the suicidal death of erythrocytes [8], an effect reversed by vitamin $\mathrm{D}$ deficient diet and thus requiring enhanced $1,25(\mathrm{OH})_{2} \mathrm{D}_{3}$ formation [8]. Eryptosis is characterized by erythrocyte shrinkage and cell membrane scrambling [23]. Eryptosis is triggered by increase of cytosolic $\mathrm{Ca}^{2+}$ activity $\left(\left[\mathrm{Ca}^{2+}\right]_{\mathrm{i}}\right)[24]$, which may result from $\mathrm{Ca}^{2+}$ entry through $\mathrm{Ca}^{2+}$ permeable cation channels $[25,26]$. Increased $\left[\mathrm{Ca}^{2+}\right]_{\mathrm{i}}$ triggers cell shrinkage by activating $\mathrm{Ca}^{2+}$ sensitive $\mathrm{K}^{+}$channels $[27,28]$ with subsequent cellular $\mathrm{K}^{+}$exit, cell membrane hyperpolarization, $\mathrm{Cl}^{-}$exit and thus cellular $\mathrm{KCl}$ loss together with osmotically obliged water [29]. Increased $\left[\mathrm{Ca}^{2+}\right]_{\mathrm{i}}$ further triggers cell membrane scrambling with translocation of phosphatidylserine to the erythrocyte surface [30]. Further stimulators of eryptosis include hyperosmotic shock [23], energy depletion [31], caspase activation [3236] and oxidative stress [37]. Eryptosis is further influenced by several kinases including AMP activated kinase AMPK [26], cGMP dependent protein kinase [38], Janus activated kinase JAK3 [39], casein kinase [40, 41], p38 kinase [42], PAK2 kinase [43] as well as sorafenib [44] and sunitinib [45] sensitive kinases.

As eryptosis is triggered by klotho deficiency [8], and klotho expression is downregulated by dehydration [2], the present study explored, whether dehydration impacts on eryptosis. To this end, $\left[\mathrm{Ca}^{2+}\right]_{\mathrm{i}}$, cell volume and phosphatidylserine exposure at the cell surface were determined in erythrocytes drawn from hydrated and water deprived mice.

\section{Materials and Methods}

\section{Mice}

All animal experiments were conducted according to the German law for the welfare of animals and were approved by local authorities. Experiments were performed in male C57Bl6 mice ( $n=6$ each group) at the age of 7 weeks. The mice received control food (SSniff, Soest, Germany) throughout the study. The mice had either access to drinking water ad libitum or were water deprived for 36 hours [1].

\section{Determination of plasma concentrations}

To collect blood specimens, animals were lightly anaesthetized with isoflurane (Abott, WiesbadenDelkenheim, Germany) and about 50 - $200 \mu$ of blood was withdrawn into heparinized capillaries by puncturing the retro-orbital plexus. Plasma osmolarity was measured by the vapour pressure method, plasma 1,25(OH) $)_{2} \mathrm{D}_{3}$ concentrations (IDS, Boldon, UK) and plasma aldosterone concentrations (ADI, San Antonio, USA) were determined utilizing a commercial ELISA Kit, serum $\mathrm{Ca}^{2+}$ concentration was measured by a photometric method (FUJI FDC 3500i, Sysmex, Norsted, Germany).

\section{Solutions}

Experiments were performed at $37^{\circ} \mathrm{C}$ in Ringer solution containing (in $\mathrm{mM}$ ) $125 \mathrm{NaCl}, 5 \mathrm{KCl}, 1 \mathrm{MgSO}_{4^{\prime}}$ $32 \mathrm{~N}-2$-hydroxyethylpiperazine-N-2-ethanesulfonic acid (HEPES)/ $\mathrm{NaOH}$ (pH 7.4), 5 glucose, $1 \mathrm{CaCl}_{2}$. Where indicated, $100 \mu \mathrm{M}$ tert-butyl-hydroxyl-peroxide (tert-BOOH, Sigma, Taufkirchen, Germany) was used to induce oxidative stress, $1 \mu \mathrm{M} \mathrm{Ca}^{2+}$ ionophore ionomycin (Sigma, Taufkirchen, Germany) to increase $\left[\mathrm{Ca}^{2+}\right]_{i^{\prime}}$ 


\section{Kidney \\ Blood Pressure Research}

Kidney Blood Press Res 2013;37:567-578

\begin{tabular}{l|l}
\hline DOI: 10.1159/000355737 & (c 2013 S. Karger AG, Basel \\
\hline
\end{tabular}

Publisned online: November 30, 2013 www.karger.com $/ \mathrm{kbr}$

Fig. 1. Plasma osmolarity, aldosterone, $1,25(\mathrm{OH})_{2} \mathrm{D}_{3}$ and calcium concentrations in hydrated and dehydrated mice. Arithmetic means \pm SEM $(n=5-6)$ of $(A)$ plasma osmolarity (B) plasma aldosterone concentration (C) plasma $1,25(\mathrm{OH})_{2} \mathrm{D}_{3}$ concentration and (D) plasma calcium concentration in hydrated (white bars) and 36 hours dehydrated (black bars) mice. * $(\mathrm{p}<0.05), * *(\mathrm{p}<0.01)$ and $* * * \quad(\mathrm{p}<0.001)$ indicate significant differences from the respective hydrated animals (t-test).

Abed et al.: Dehydration Induced Eryptosis

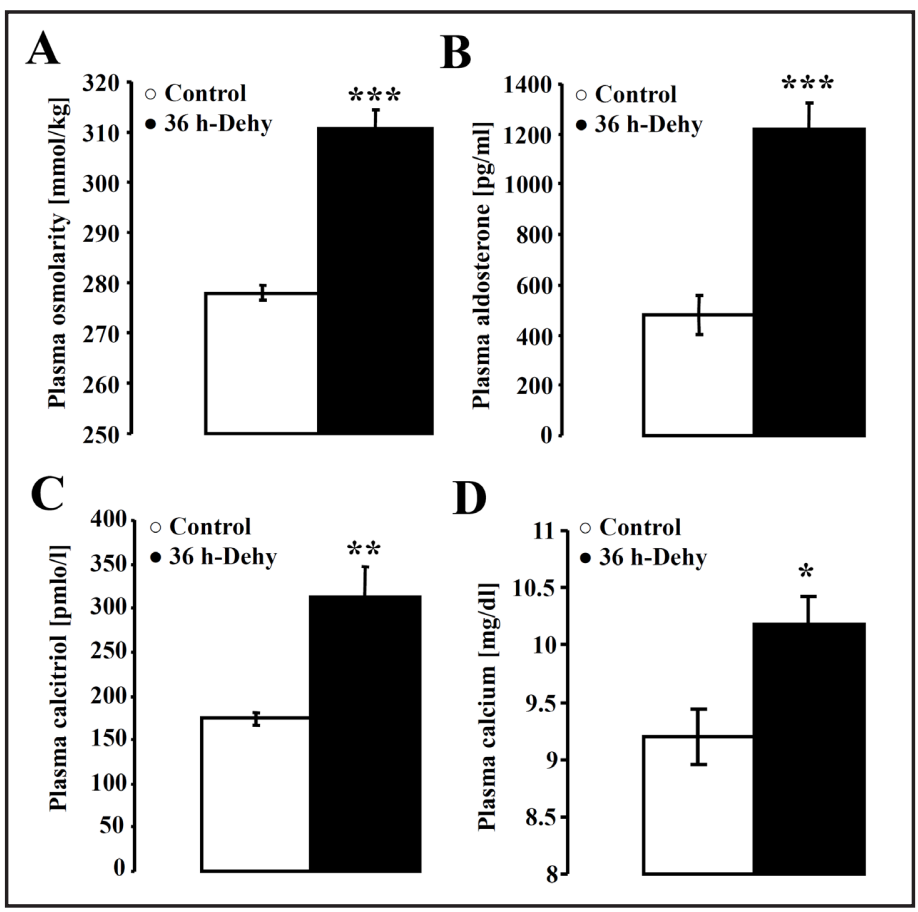

glucose removal to cause energy depletion, or osmolarity increased (addition of $500 \mathrm{mM}$ sucrose) to induce hyperosmotic shock.

\section{Phosphatidylserine exposure}

To determine annexin $\mathrm{V}$ binding, reflecting phosphatidylserine exposure at the cell surface, erythrocytes were washed once in Ringer solution $+4 \mathrm{mM} \mathrm{CaCl}_{2}$. The cells were then stained with Annexin-V-FITC (1:200 dilution; ImmunoTools, Friesoythe, Germany). After $15 \mathrm{~min}$, samples were measured by flow cytometric analysis (FACS-Calibur from Becton Dickinson, Heidelberg, Germany). Annexin V-fluorescence intensity was measured at an excitation wavelength of $488 \mathrm{~nm}$ and an emission wavelength of $530 \mathrm{~nm}$.

\section{Statistics}

Data are expressed as arithmetic means \pm SEM. As indicated in the figure legends, statistical analysis was made using ANOVA with Tukey's test as post test and $t$ test as appropriate. $\mathrm{n}$ denotes the number of different erythrocyte specimens studied.

\section{Results}

The present study explored the effect of water deprivation on eryptosis, the suicidal erythrocyte death. To this end, mice were exposed to a 36 hours period of water deprivation and blood drawn for analysis of osmolarity, hormone concentrations and plasma calcium levels as well as phosphatidylserine exposure of erythrocytes. As illustrated in Fig. 1, a 36 hours water deprivation significantly increased plasma osmolarity, plasma aldosterone concentration, plasma $1,25(\mathrm{OH})_{2} \mathrm{D}_{3}$ concentration and plasma concentration of calcium.

Fig. 2 illustrates the effect of dehydration on annexin $\mathrm{V}$ binding, a measure of phosphatidylserine exposure at the erythrocyte surface. In freshly drawn blood the percentage of annexin $\mathrm{V}$ binding erythrocytes was not significantly different between dehydrated and hydrated animals. Following exposure to Ringer solution, the percentage of annexin $\mathrm{V}$ binding erythrocytes increased gradually. This increase was significantly steeper in erythrocytes from dehydrated animals than in erythrocytes from hydrated animals. 


\section{Kidney \\ Blood Pressure Research}

Fig. 2. Effect of dehydration on spontaneous phosphatidylserine exposure. A,B. Original histogram of annexin $\mathrm{V}$ binding of freshly drawn (A) or 48 hours incubated (B) erythrocytes from hydrated (grey shadows) and dehydrated (black lines) animals. C. Arithmetic means \pm SEM $(n=6)$ demonstrating annexin $\mathrm{V}$ binding of erythrocytes drawn from hydrated (open cirlces) or dehydrated (closed circles) animals following incubation for
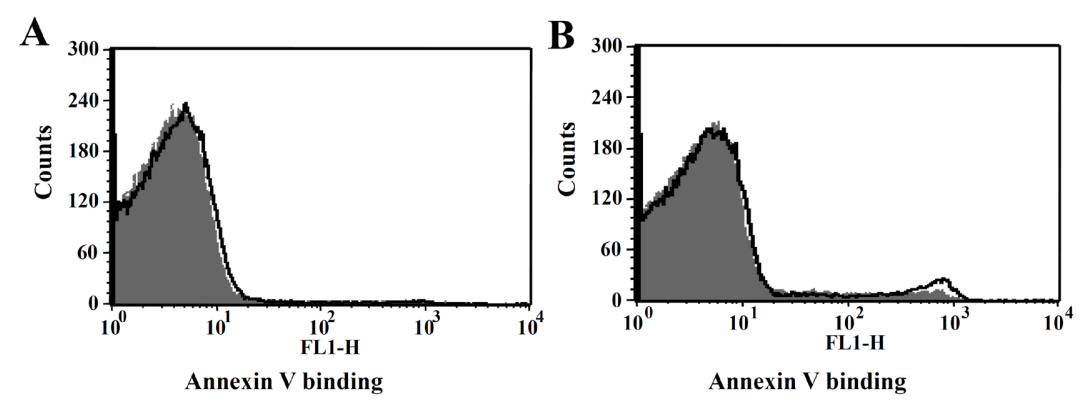

C

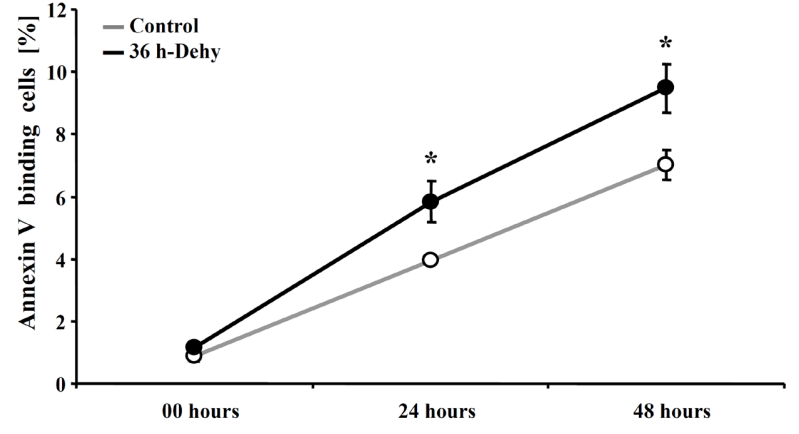

0,24 or 48 hours in Ringer solution. * $(\mathrm{p}<0.05)$ indicate significant differences from erythrocytes of hydrated animals (ANOVA).

Accordingly, following both, a 24 hours and a 48 hours incubation in Ringer, the percentage of annexin $V$ binding dehydrated erythrocytes was significantly higher than the percentage of annexin $V$ binding hydrated erythrocytes. Thus, dehydration accelerated the spontaneous development of phosphatidylserine exposure.

Further experiments explored whether dehydration affects the sensitivity of erythrocytes to known triggers of eryptosis. In order to test the sensitivity to increased cytosolic $\mathrm{Ca}^{2+}$ activity, the erythrocytes were exposed for $30 \mathrm{~min}$ to the $\mathrm{Ca}^{2+}$ ionophore ionomycin $(1 \mu \mathrm{M})$. As illustrated in Fig. 3, ionomycin treatment was followed by a sharp increase of phosphatidylserine exposure in both, hydrated and dehydrated erythrocytes. The phosphatidylserine exposure following ionomycin treatment was, however, significantly higher in dehydrated than in hydrated erythrocytes.

In order to test whether hydration influences the sensitivity of erythrocytes to enegry depletion, the erythrocytes were exposed for 12 hours to either glucose containing or glucose deprived Ringer solution. As shown in Fig. 4, glucose withdrawal was followed by a marked increase of phosphatidylserine exposure in both, hydrated and dehydrated erythrocytes. Again, the phosphatidylserine exposure following glucose deprivation was significantly higher in dehydrated than in hydrated erythrocytes.

The sensitivity of erythrocytes to hyperosmotic shock was tested by increasing the osmolarity of the Ringer solution by addition of $500 \mathrm{mM}$ sucrose. The erythrocytes were exposed for 2 hours to either isotonic or hypertonic Ringer solution. As demonstrated in Fig. 5 , hyperosmotic shock was followed by an increase of phosphatidylserine exposure in both, hydrated and dehydrated erythrocytes. Again, the phosphatidylserine exposure following osmotic shock was significantly higher in dehydrated than in hydrated erythrocytes.

Tert-butylhydroperoxide ( $\mathrm{t}-\mathrm{BOOH})$ was utilized in order to test the sensitivity of erythrocytes against oxidative stress. The erythrocytes were exposed for $30 \mathrm{~min}$ to Ringer solution either without or with $100 \mu \mathrm{M}$ t-BOOH. As shown in Fig. 6, t-BOOH treatment was followed by an increase of phosphatidylserine abundance at the erythrocyte surface in both, 


\section{Kidney \\ Blood Pressure \\ Research}

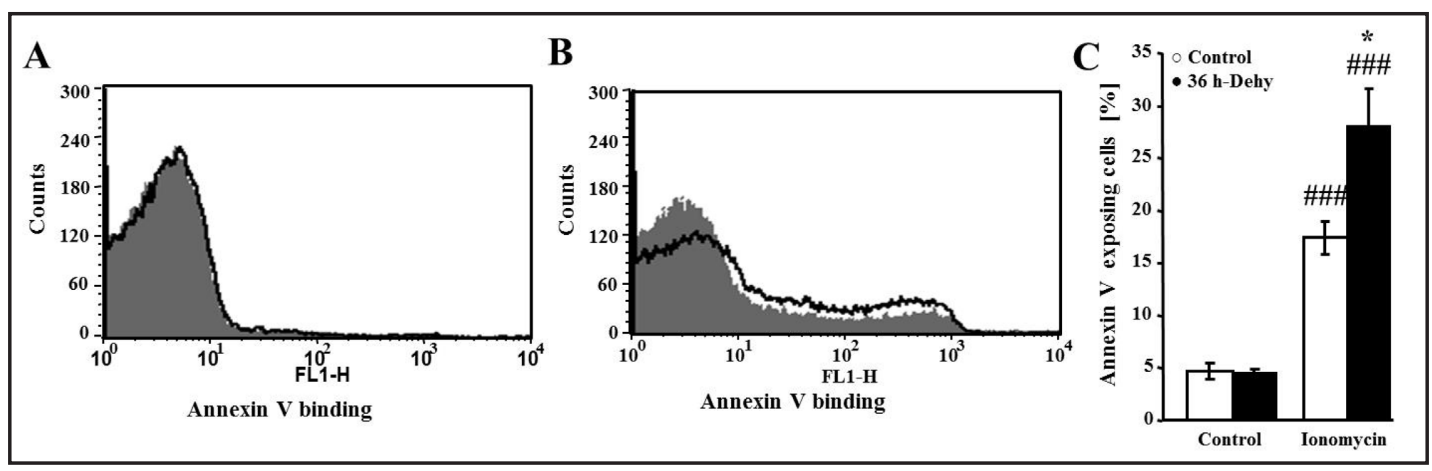

Fig. 3. Effect of $\mathrm{Ca}^{2+}$ ionophore ionomycin on phosphatidylserine exposure of erythrocytes drawn from hydrated and dehydrated animals. A,B. Original histograms demonstrating annexin V binding of erythrocytes drawn from hydrated (grey areas) or dehydrated (black lines) animals following exposure for 30 min to Ringer solution without (A) or with (B) presence of $1 \mu \mathrm{M} \mathrm{Ca}^{2+}$ ionophore ionomycin. C. Arithmetic means \pm SEM $(n=6)$ of annexin V binding erythrocytes, drawn from hydrated (white bars) or dehydrated (black bars) animals, following incubation for $30 \mathrm{~min}$ to Ringer solution without (left bars, control) or with (right bars, ionomycin) presence of $\mathrm{Ca}^{2+}$ ionophore ionomycin $(1 \mu \mathrm{M}) * *(\mathrm{p}<0.05)$ indicates significant difference to erythrocytes drawn from hydrated animals, \#\#\# ( $p<0.001)$ indicates significant difference to absence of ionomycin (ANOVA).

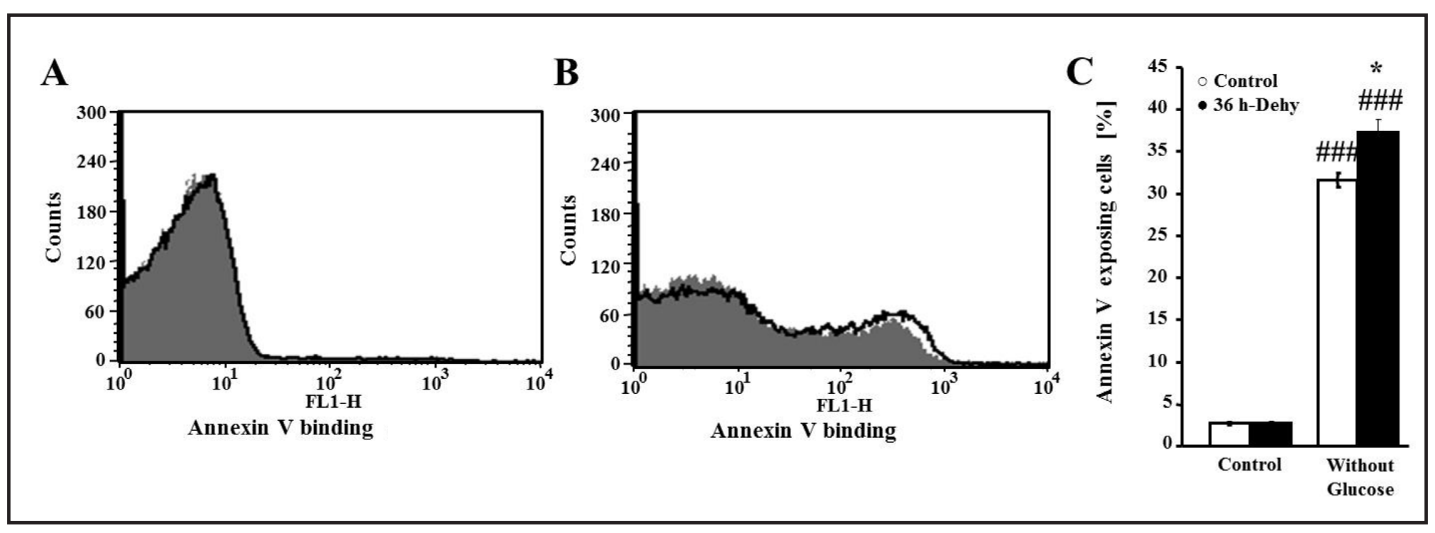

Fig. 4. Effect of glucose deprivation on phosphatidylserine exposure of erythrocytes drawn from hydrated and dehydrated animals. A,B. Original histograms demonstrating annexin V binding of erythrocytes drawn from hydrated (grey areas) or dehydrated (black lines) animals following exposure for $12 \mathrm{~h}$ to Ringer solution with (A) or without (B) presence of glucose. C. Arithmetic means \pm SEM $(n=6)$ of annexin V binding erythrocytes, drawn from hydrated (white bars) or dehydrated (black bars) animals, following incubation for $12 \mathrm{~h}$ to Ringer solution with (left bars, control) or without (right bars, without glucose) presence of glucose. ${ }^{*}(p<0.05)$ indicates significant difference to erythrocytes drawn from hydrated animals, \#\#\#(p<0.001) indicates significant difference to presence of glucose (ANOVA).

hydrated and dehydrated erythrocytes. As already shown for the other triggers of eryptosis, the phosphatidylserine abundance following t-BOOH treatment was significantly higher in dehydrated than in hydrated erythrocytes.

\section{Discussion}

The presentstudy reveals an influence of dehydration on the phosphatidylserine abundance at the erythrocyte cell membrane surface. Accordingly, dehydration fosters the development 


\section{Kidney \\ Blood Pressure \\ Research}

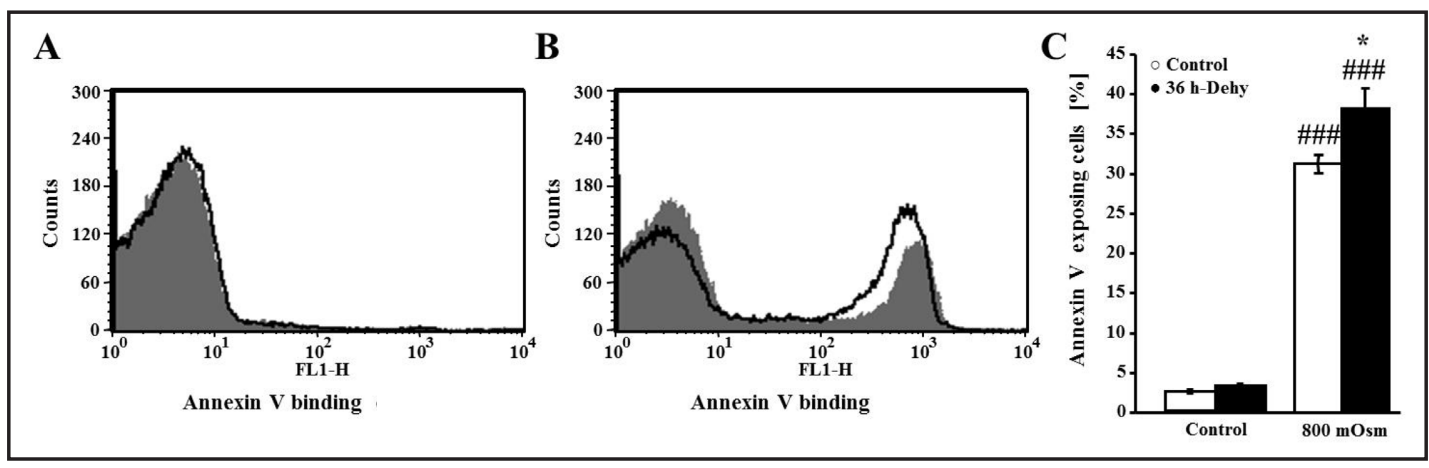

Fig. 5. Effect of hyperosmotic shock on phosphatidylserine exposure of erythrocytes drawn from hydrated and dehydrated animals. A,B. Original histograms demonstrating annexin $\mathrm{V}$ binding of erythrocytes drawn from hydrated (grey areas) or dehydrated (black lines) animals following exposure for $2 \mathrm{~h}$ to isotonic (A) or hypertonic $(B, 500 \mathrm{mM}$ sucrose added) Ringer solution. C. Arithmetic means \pm SEM $(\mathrm{n}=6)$ of annexin $V$ binding erythrocytes, drawn from hydrated (white bars) or dehydrated (black bars) animals, following incubation for $2 \mathrm{~h}$ to isotonic (left bars, control) or hypertonic (right bars, $500 \mathrm{mM}$ sucrose added) Ringer solution. ${ }^{*}(\mathrm{p}<0.05)$ indicates significant difference to erythrocytes drawn from hydrated animals, \#\#\#(p<0.001) indicates significant difference to isotonic Ringer (ANOVA).

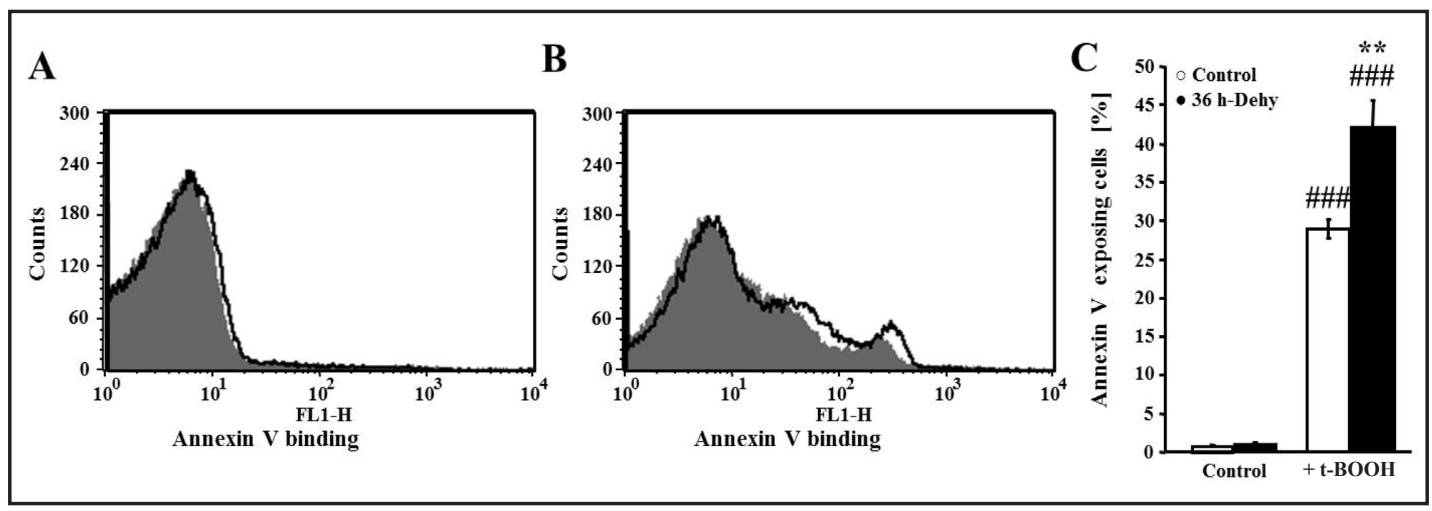

Fig. 6. Effect of oxidative stress on phosphatidylserine exposure of erythrocytes drawn from hydrated and dehydrated animals. A,B. Original histograms demonstrating annexin V binding of erythrocytes drawn from hydrated (grey areas) or dehydrated (black lines) animals following exposure for 30 min to Ringer solution without (A) or with (B) presence of $100 \mu \mathrm{M}$ tert-butyl-hydroperoxide. C. Arithmetic means \pm SEM $(n=6)$ of annexin $\mathrm{V}$ binding erythrocytes, drawn from hydrated (white bars) or dehydrated (black bars) animals, following incubation for 30 min to Ringer solution without (left bars, control) or with (right bars, $+\mathrm{t}-\mathrm{BOOH}$ ) presence of tert-butyl-hydroperoxide $(100 \mu \mathrm{M}) .{ }^{* *}(\mathrm{p}<0.01)$ indicates significant difference to erythrocytes drawn from hydrated animals, \#\#\#( $<<0.001)$ indicates significant difference to absence of tert-butyl-hydroperoxide (ANOVA).

of eryptosis, the suicidal death of erythrocytes. The difference of phosphatidylserine exposure in freshly drawn erythrocytes is not significantly different between hydrated and dehydrated animals. It must be kept in mind that phosphatidylserine exposing erythrocytes are rapidly cleared from circulating blood [23]. Thus, appreciable effects on the percentage phosphatidylserine exposing erythrocytes could only be expected following dramatic stimulation of eryptosis. This is apparently not the case following dehydration. The in vitro incubation of the erythrocytes discloses the slight but statistically significant difference between erythrocytes from dehydrated and erythrocytes from hydrated animals. 


\section{Kidney \\ Blood Pressure Research}

The present study did not elucidate the mechanisms accounting for the enhanced susceptibility of erythrocytes to triggers of eryptosis following dehydration of the animal. Notably, erythrocytes isolated from hydrated and dehydrated animals have subsequently been incubated in the same Ringer solution. Thus, the trigger of eryptosis remained effective even following removal of plasma. Thus, plasma osmolarity and hormone levels are not immediately involved in the observed stimulation of erythrocyte cell membrane scrambling following dehydration. Hormones, plasma osmolarity, or other hydration sensitive plasma components could, however, lead to lasting changes of erythrocyte properties rendering them more susceptible to triggers of eryptosis.

The sensitization of erythrocytes to stimulators of eryptosis by dehydration may be important in the presence of other stimulators of eryptosis or in clinical conditions associated with enhanced eryptosis. Eryptosis is stimulated by a wide variety of xenobiotics [45-76] and eryptosis is increased in several clinical disorders [23], including diabetes [36, 77, 78], renal insufficiency [79], hemolytic uremic syndrome [80], sepsis [81], malaria [82-86], sickle cell disease [87], Wilson's disease [85], iron deficiency [88], malignancy [89], phosphate depletion [90], and metabolic syndrome [72]. According to the present observations, dehydration may augment the effect of eryptosis inducing drugs or disorders.

Phosphatidylserine exposure fosters the adhesion of erythrocytes to endothelial CXCL16/SR PSO [91], which may, at least in theory, compromize microcirculation and thus interfere with blood flow [91-96]. Phosphatidylserine exposure may further foster blood clotting with subsequent triggering of thrombosis $[92,97,98]$. It is thus tempting to speculate that phosphatidylserine exposure of erythrocytes contributes to the well known stimulation of thrombosis by dehydration [99-101].

\section{Conclusions}

Dehydration has a subtle stimulating effect on phosphatidylerine scrambling in the erythrocyte cell membrane and may augment the phosphatidylserine scrambling following excess $\mathrm{Ca}^{2+}$ entry, energy depletion, hyperosmotic shock an oxidative stress.

\section{Conflict of Interests}

Competing interests: the authors have no competing interests.

\section{Acknowledgements}

The authors acknowledge the meticulous preparation of the manuscript by Ali Soleimanpour. The study was supported by the Deutsche Forschungsgemeinschaft and the Open Access Publishing Fund of Tuebingen University.

\section{References}

1 Tang C, Zelenak C, Volkl J, Eichenmuller M, Regel I, Frohlich H, Kempe D, Jimenez L, Le Bellego L, Vergne S, Lang F: Hydration-sensitive gene expression in brain. Cell Physiol Biochem 2011;27:757-768.

2 Tang C, Pathare G, Michael D, Fajol A, Eichenmuller M, Lang F: Downregulation of Klotho expression by dehydration. Am J Physiol Renal Physiol 2011;301:F745-750. 


\section{Kidney \\ Bloód Pressure Research}

3 Hu MC, Shiizaki K, Kuro-o M, Moe OW: Fibroblast growth factor 23 and Klotho: physiology and pathophysiology of an endocrine network of mineral metabolism. Annu Rev Physiol 2013;75:503-533.

$>4$

$>5$

$>6$

$>7$

$>8$

$>9$

$>10$

$>11$

$>12$

$>13$

$>14$

$>15$

$-16$ Imaizumi T: Angiogenesis and vasculogenesis are impaired in the precocious-aging klotho mouse. Circulation 2004;110:1148-1155.

-17 Takeshita K, Fujimori T, Kurotaki Y, Honjo H, Tsujikawa H, Yasui K, Lee JK, Kamiya K, Kitaichi K, Yamamoto K, Ito M, Kondo T, Iino S, Inden Y, Hirai M, Murohara T, Kodama I, Nabeshima Y: Sinoatrial node dysfunction and early unexpected death of mice with a defect of klotho gene expression. Circulation 2004;109:17761782.

-18 Torres PU, Prie D, Molina-Bletry V, Beck L, Silve C, Friedlander G: Klotho: an antiaging protein involved in mineral and vitamin D metabolism. Kidney Int 2007;71:730-737.

19 Tuohimaa P: Vitamin D and aging. J Steroid Biochem Mol Biol 2009;114:78-84.

-20 Dermaku-Sopjani M, Sopjani M, Saxena A, Shojaiefard M, Bogatikov E, Alesutan I, Eichenmuller M, Lang F: Downregulation of NaPi-IIa and NaPi-IIb Na-coupled phosphate transporters by coexpression of Klotho. Cell Physiol Biochem 2011;28:251-258.

21 Hu MC, Shi M, Zhang J, Pastor J, Nakatani T, Lanske B, Razzaque MS, Rosenblatt KP, Baum MG, Kuro-o M, Moe OW: Klotho: a novel phosphaturic substance acting as an autocrine enzyme in the renal proximal tubule. FASEB J 2010;24:3438-3450.

-22 Yoshida T, Fujimori T, Nabeshima Y: Mediation of unusually high concentrations of 1,25-dihydroxyvitamin D in homozygous klotho mutant mice by increased expression of renal 1alpha-hydroxylase gene. Endocrinology 2002;143:683-689.

23 Lang F, Gulbins E, Lerche H, Huber SM, Kempe DS, F”ller M: Eryptosis, a window to systemic disease. Cell Physiol Biochem 2008;22 373-380.

-24 Lang F, Gulbins E, Lang PA, Zappulla D, Foller M: Ceramide in suicidal death of erythrocytes. Cell Physiol Biochem 2010;26:21-28.

25 Foller M, Kasinathan RS, Koka S, Lang C, Shumilina E, Birnbaumer L, Lang F, Huber SM: TRPC6 contributes to the $\mathrm{Ca}(2+)$ leak of human erythrocytes. Cell Physiol Biochem 2008;21:183-192. 


\section{Kidney \\ Blood Pressure Research}

-26 Foller M, Sopjani M, Koka S, Gu S, Mahmud H, Wang K, Floride E, Schleicher E, Schulz E, Munzel T, Lang F: Regulation of erythrocyte survival by AMP-activated protein kinase. FASEB J 2009;23:1072-1080.

27 Bookchin RM, Ortiz OE, Lew VL: Activation of calcium-dependent potassium channels in deoxygenated sickled red cells. Prog Clin Biol Res 1987;240:193-200.

-28 Brugnara C, de Franceschi L, Alper SL: Inhibition of $\mathrm{Ca}(2+)$-dependent $\mathrm{K}+$ transport and cell dehydration in sickle erythrocytes by clotrimazole and other imidazole derivatives. J Clin Invest 1993;92:520-526.

-29 Lang PA, Kaiser S, Myssina S, Wieder T, Lang F, Huber SM: Role of Ca2+-activated K+ channels in human erythrocyte apoptosis. Am J Physiol Cell Physiol 2003;285:C1553-C1560.

-30 Berg CP, Engels IH, Rothbart A, Lauber K, Renz A, Schlosser SF, Schulze-Osthoff K, Wesselborg S: Human mature red blood cells express caspase- 3 and caspase-8, but are devoid of mitochondrial regulators of apoptosis. Cell Death Differ 2001;8:1197-1206.

31 Klarl BA, Lang PA, Kempe DS, Niemoeller OM, Akel A, Sobiesiak M, Eisele K, Podolski M, Huber SM, Wieder T, Lang F: Protein kinase C mediates erythrocyte "programmed cell death" following glucose depletion. Am J Physiol Cell Physiol 2006;290:C244-C253.

-32 Bhavsar SK, Bobbala D, Xuan NT, Foller M, Lang F: Stimulation of suicidal erythrocyte death by alpha-lipoic acid. Cell Physiol Biochem 2010;26:859-868.

33 Foller M, Huber SM, Lang F: Erythrocyte programmed cell death. IUBMB Life 2008;60:661-668.

34 Foller M, Mahmud H, Gu S, Wang K, Floride E, Kucherenko Y, Luik S, Laufer S, Lang F: Participation of leukotriene C(4) in the regulation of suicidal erythrocyte death. J Physiol Pharmacol 2009;60:135-143.

-35 Lau IP, Chen H, Wang J, Ong HC, Leung KC, Ho HP, Kong SK: In vitro effect of CTAB- and PEG-coated gold nanorods on the induction of eryptosis/erythroptosis in human erythrocytes. Nanotoxicology 2012;6:847856.

36 Maellaro E, Leoncini S, Moretti D, Del Bello B, Tanganelli I, De Felice C, Ciccoli L: Erythrocyte caspase-3 activation and oxidative imbalance in erythrocytes and in plasma of type 2 diabetic patients. Acta Diabetol 2013;50:489-495.

37 Brand VB, Sandu CD, Duranton C, Tanneur V, Lang KS, Huber SM, Lang F: Dependence of Plasmodium falciparum in vitro growth on the cation permeability of the human host erythrocyte. Cell Physiol Biochem 2003;13:347-356.

-38 Foller M, Feil S, Ghoreschi K, Koka S, Gerling A, Thunemann M, Hofmann F, Schuler B, Vogel J, Pichler B, Kasinathan RS, Nicolay JP, Huber SM, Lang F, Feil R: Anemia and splenomegaly in cGKI-deficient mice. Proc Natl Acad Sci USA 2008;105:6771-6776.

-39 Bhavsar SK, Gu S, Bobbala D, Lang F: Janus kinase 3 is expressed in erythrocytes, phosphorylated upon energy depletion and involved in the regulation of suicidal erythrocyte death. Cell Physiol Biochem 2011;27:547-556.

40 Kucherenko Y, Zelenak C, Eberhard M, Qadri SM, Lang F: Effect of casein kinase 1alpha activator pyrvinium pamoate on erythrocyte ion channels. Cell Physiol Biochem 2012;30:407-417.

41 Zelenak C, Eberhard M, Jilani K, Qadri SM, Macek B, Lang F: Protein kinase CK1alpha regulates erythrocyte survival. Cell Physiol Biochem 2012;29:171-180.

42 Gatidis S, Zelenak C, Fajol A, Lang E, Jilani K, Michael D, Qadri SM, Lang F: p38 MAPK activation and function following osmotic shock of erythrocytes. Cell Physiol Biochem 2011;28:1279-1286.

-43 Zelenak C, Foller M, Velic A, Krug K, Qadri SM, Viollet B, Lang F, Macek B: Proteome analysis of erythrocytes lacking AMP-activated protein kinase reveals a role of PAK2 kinase in eryptosis. J Proteome Res 2011;10:1690-1697.

44 Lupescu A, Shaik N, Jilani K, Zelenak C, Lang E, Pasham V, Zbidah M, Plate A, Bitzer M, Foller M, Qadri SM, Lang F: Enhanced Erythrocyte Membrane Exposure of Phosphatidylserine Following Sorafenib Treatment: An in vivo and in vitro Study. Cell Physiol Biochem 2012;30:876-888.

45 Shaik N, Lupescu A, Lang F: Sunitinib-sensitive suicidal erythrocyte death. Cell Physiol Biochem 2012;30:512-522.

46 Abed M, Towhid ST, Mia S, Pakladok T, Alesutan I, Borst O, Gawaz M, Gulbins E, Lang F: Sphingomyelinaseinduced adhesion of eryptotic erythrocytes to endothelial cells. Am J Physiol Cell Physiol 2012;303:C991999.

-47 Abed M, Towhid ST, Shaik N, Lang F: Stimulation of suicidal death of erythrocytes by rifampicin. Toxicology 2012;302:123-128. 


\section{Kidney \\ Blood Pressure Research}

48 Bottger E, Multhoff G, Kun JF, Esen M: Plasmodium falciparum-infected erythrocytes induce granzyme B by NK cells through expression of host-Hsp70. PLoS One 2012;7:e33774.

49 Felder KM, Hoelzle K, Ritzmann M, Kilchling T, Schiele D, Heinritzi K, Groebel K, Hoelzle LE: Hemotrophic mycoplasmas induce programmed cell death in red blood cells. Cell Physiol Biochem 2011;27:557-564.

50 Firat U, Kaya S, Cim A, Buyukbayram H, Gokalp O, Dal MS, Tamer MN: Increased caspase-3 immunoreactivity of erythrocytes in STZ diabetic rats. Exp Diabetes Res 2012;2012:316384.

51 Ganesan S, Chaurasiya ND, Sahu R, Walker LA, Tekwani BL: Understanding the mechanisms for metabolism-linked hemolytic toxicity of primaquine against glucose 6-phosphate dehydrogenase deficient human erythrocytes: evaluation of eryptotic pathway. Toxicology 2012;294:54-60.

52 Gao M, Cheung KL, Lau IP, Yu WS, Fung KP, Yu B, Loo JF, Kong SK: Polyphyllin D induces apoptosis in human erythrocytes through $\mathrm{Ca}(2)(+)$ rise and membrane permeabilization. Arch Toxicol 2012;86:741-752.

53 Ghashghaeinia M, Cluitmans JC, Akel A, Dreischer P, Toulany M, Koberle M, Skabytska Y, Saki M, Biedermann T, Duszenko M, Lang F, Wieder T, Bosman GJ: The impact of erythrocyte age on eryptosis. Br J Haematol 2012;157:606-614.

54 Ghashghaeinia M, Toulany M, Saki M, Bobbala D, Fehrenbacher B, Rupec R, Rodemann HP, Ghoreschi K, Rocken M, Schaller M, Lang F, Wieder T: The NFkB pathway inhibitors Bay 11-7082 and parthenolide induce programmed cell death in anucleated Erythrocytes. Cell Physiol Biochem 2011;27:45-54.

55 Jilani K, Lupescu A, Zbidah M, Abed M, Shaik N, Lang F: Enhanced Apoptotic Death of Erythrocytes Induced by the Mycotoxin Ochratoxin A. Kidney Blood Press Res 2012;36:107-118.

56 Jilani K, Lupescu A, Zbidah M, Shaik N, Lang F: Withaferin A-stimulated Ca(2+) entry, ceramide formation and suicidal death of erythrocytes. Toxicol In Vitro 2013;27:52-58.

57 Kucherenko YV, Lang F: Inhibitory Effect of Furosemide on Non-Selective Voltage-Independent Cation Channels in Human Erythrocytes. Cell Physiol Biochem 2012;30:863-875.

-58 Lang E, Jilani K, Zelenak C, Pasham V, Bobbala D, Qadri SM, Lang F: Stimulation of suicidal erythrocyte death by benzethonium. Cell Physiol Biochem 2011;28:347-354.

59 Lang E, Qadri SM, Jilani K, Zelenak C, Lupescu A, Schleicher E, Lang F: Carbon monoxide-sensitive apoptotic death of erythrocytes. Basic Clin Pharmacol Toxicol 2012;111:348-355.

60 Lang F, Qadri SM: Mechanisms and significance of eryptosis, the suicidal death of erythrocytes. Blood Purif 2012;33:125-130.

61 Lupescu A, Jilani K, Zbidah M, Lang E, Lang F: Enhanced Ca(2+) Entry, Ceramide Formation, and Apoptotic Death of Erythrocytes Triggered by Plumbagin. J Nat Prod 2012;6:847-856.

62 Lupescu A, Jilani K, Zbidah M, Lang F: Induction of apoptotic erythrocyte death by rotenone. Toxicology 2012;300:132-137.

63 Lupescu A, Jilani K, Zelenak C, Zbidah M, Qadri SM, Lang F: Hexavalent chromium-induced erythrocyte membrane phospholipid asymmetry. Biometals 2012;25:309-318.

64 Polak-Jonkisz D, Purzyc L: Ca Influx versus Efflux during Eryptosis in Uremic Erythrocytes. Blood Purif 2012;34:209-210.

65 Qadri SM, Bauer J, Zelenak C, Mahmud H, Kucherenko Y, Lee SH, Ferlinz K, Lang F: Sphingosine but not sphingosine-1-phosphate stimulates suicidal erythrocyte death. Cell Physiol Biochem 2011;28:339-346.

66 Qadri SM, Kucherenko Y, Lang F: Beauvericin induced erythrocyte cell membrane scrambling. Toxicology 2011;283:24-31.

67 Qadri SM, Kucherenko Y, Zelenak C, Jilani K, Lang E, Lang F: Dicoumarol activates Ca2+-permeable cation channels triggering erythrocyte cell membrane scrambling. Cell Physiol Biochem 2011;28:857-864.

-68 Qian EW, Ge DT, Kong SK: Salidroside protects human erythrocytes against hydrogen peroxide-induced apoptosis. J Nat Prod 2012;75:531-537.

69 Shaik N, Zbidah M, Lang F: Inhibition of $\mathrm{Ca}(2+)$ entry and suicidal erythrocyte death by naringin. Cell Physiol Biochem 2012;30:678-686.

70 Vota DM, Maltaneri RE, Wenker SD, Nesse AB, Vittori DC: Differential Erythropoietin Action upon Cells Induced to Eryptosis by Different Agents. Cell Biochem Biophys 2013;65:145-157.

71 Weiss E, Cytlak UM, Rees DC, Osei A, Gibson JS: Deoxygenation-induced and Ca(2+) dependent phosphatidylserine externalisation in red blood cells from normal individuals and sickle cell patients. Cell Calcium 2012;51:51-56. 


\section{Kidney \\ Blood Pressure Research}

72 Zappulla D: Environmental stress, erythrocyte dysfunctions, inflammation, and the metabolic syndrome: adaptations to CO2 increases? J Cardiometab Syndr 2008;3:30-34.

73 Zbidah M, Lupescu A, Jilani K, Lang F: Stimulation of Suicidal Erythrocyte Death by Fumagillin. Basic Clin Pharmacol Toxicol 2013;112:346-351.

-74 Zbidah M, Lupescu A, Shaik N, Lang F: Gossypol-induced suicidal erythrocyte death. Toxicology 2012;302:101-105.

75 Zelenak C, Pasham V, Jilani K, Tripodi PM, Rosaclerio L, Pathare G, Lupescu A, Faggio C, Qadri SM, Lang F: Tanshinone IIA stimulates erythrocyte phosphatidylserine exposure. Cell Physiol Biochem 2012;30:282294.

-76 Lang E, Qadri SM, Lang F: Killing me softly - suicidal erythrocyte death. Int J Biochem Cell Biol 2012;44:1236-1243.

-77 Calderon-Salinas JV, Munoz-Reyes EG, Guerrero-Romero JF, Rodriguez-Moran M, Bracho-Riquelme RL, Carrera-Gracia MA, Quintanar-Escorza MA: Eryptosis and oxidative damage in type 2 diabetic mellitus patients with chronic kidney disease. Mol Cell Biochem 2011;357:171-179.

78 Nicolay JP, Schneider J, Niemoeller OM, Artunc F, Portero-Otin M, Haik G, Jr., Thornalley PJ, Schleicher E, Wieder T, Lang F: Stimulation of suicidal erythrocyte death by methylglyoxal. Cell Physiol Biochem 2006;18:223-232.

79 Myssina S, Huber SM, Birka C, Lang PA, Lang KS, Friedrich B, Risler T, Wieder T, Lang F: Inhibition of erythrocyte cation channels by erythropoietin. J Am Soc Nephrol 2003;14:2750-2757.

-80 Lang PA, Beringer O, Nicolay JP, Amon O, Kempe DS, Hermle T, Attanasio P, Akel A, Schafer R, Friedrich B, Risler T, Baur M, Olbricht CJ, Zimmerhackl LB, Zipfel PF, Wieder T, Lang F: Suicidal death of erythrocytes in recurrent hemolytic uremic syndrome. J Mol Med 2006;84:378-388.

-81 Kempe DS, Akel A, Lang PA, Hermle T, Biswas R, Muresanu J, Friedrich B, Dreischer P, Wolz C, Schumacher U, Peschel A, Gotz F, Doring G, Wieder T, Gulbins E, Lang F: Suicidal erythrocyte death in sepsis. J Mol Med 2007;85:269-277.

82 Bobbala D, Alesutan I, Foller M, Huber SM, Lang F: Effect of anandamide in Plasmodium Berghei-infected mice. Cell Physiol Biochem 2010;26:355-362.

83 Foller M, Bobbala D, Koka S, Huber SM, Gulbins E, Lang F: Suicide for survival--death of infected erythrocytes as a host mechanism to survive malaria. Cell Physiol Biochem 2009;24:133-140.

84 Koka S, Bobbala D, Lang C, Boini KM, Huber SM, Lang F: Influence of paclitaxel on parasitemia and survival of Plasmodium berghei infected mice. Cell Physiol Biochem 2009;23:191-198.

85 Lang PA, Schenck M, Nicolay JP, Becker JU, Kempe DS, Lupescu A, Koka S, Eisele K, Klarl BA, Rubben H, Schmid KW, Mann K, Hildenbrand S, Hefter H, Huber SM, Wieder T, Erhardt A, Haussinger D, Gulbins E, Lang F: Liver cell death and anemia in Wilson disease involve acid sphingomyelinase and ceramide. Nat Med 2007;13:164-170.

86 Siraskar B, Ballal A, Bobbala D, Foller M, Lang F: Effect of amphotericin B on parasitemia and survival of plasmodium berghei-infected mice. Cell Physiol Biochem 2010;26:347-354.

87 Lang PA, Kasinathan RS, Brand VB, Duranton C, Lang C, Koka S, Shumilina E, Kempe DS, Tanneur V, Akel A, Lang KS, Foller M, Kun JF, Kremsner PG, Wesselborg S, Laufer S, Clemen CS, Herr C, Noegel AA, Wieder T, Gulbins E, Lang F, Huber SM: Accelerated clearance of Plasmodium-infected erythrocytes in sickle cell trait and annexin-A7 deficiency. Cell Physiol Biochem 2009;24:415-428.

-88 Kempe DS, Lang PA, Duranton C, Akel A, Lang KS, Huber SM, Wieder T, Lang F: Enhanced programmed cell death of iron-deficient erythrocytes. FASEB J 2006;20:368-370.

89 Qadri SM, Mahmud H, Lang E, Gu S, Bobbala D, Zelenak C, Jilani K, Siegfried A, Foller M, Lang F: Enhanced suicidal erythrocyte death in mice carrying a loss-of-function mutation of the adenomatous polyposis coli gene. J Cell Mol Med 2012;16:1085-1093.

90 Birka C, Lang PA, Kempe DS, Hoefling L, Tanneur V, Duranton C, Nammi S, Henke G, Myssina S, Krikov M, Huber SM, Wieder T, Lang F: Enhanced susceptibility to erythrocyte "apoptosis" following phosphate depletion. Pflugers Arch 2004;448:471-477.

-91 Borst O, Abed M, Alesutan I, Towhid ST, Qadri SM, Foller M, Gawaz M, Lang F: Dynamic adhesion of eryptotic erythrocytes to endothelial cells via CXCL16/SR-PSOX. Am J Physiol Cell Physiol 2012;302:C644-C651.

-92 Andrews DA, Low PS: Role of red blood cells in thrombosis. Curr Opin Hematol 1999;6:76-82. 


\section{Kidney \\ Blood Pressure Research}

\section{Kidney Blood Press Res 2013;37:567-578}

DOI: $10.1159 / 000355737$

Published onlıne: November 30, 2013

(C) 2013 S. Karger AG, Basel

Abed et al.: Dehydration Induced Eryptosis

$\$ 93$ Closse C, Dachary-Prigent J, Boisseau MR: Phosphatidylserine-related adhesion of human erythrocytes to vascular endothelium. Br J Haematol 1999;107:300-302.

94 Gallagher PG, Chang SH, Rettig MP, Neely JE, Hillery CA, Smith BD, Low PS: Altered erythrocyte endothelial adherence and membrane phospholipid asymmetry in hereditary hydrocytosis. Blood 2003;101:4625-

4627.

95 Pandolfi A, Di Pietro N, Sirolli V, Giardinelli A, Di Silvestre S, Amoroso L, Di Tomo P, Capani F, Consoli A, Bonomini M: Mechanisms of uremic erythrocyte-induced adhesion of human monocytes to cultured endothelial cells. J Cell Physiol 2007;213:699-709.

-96 Wood BL, Gibson DF, Tait JF: Increased erythrocyte phosphatidylserine exposure in sickle cell disease: flowcytometric measurement and clinical associations. Blood 1996;88:1873-1880.

97 Chung SM, Bae ON, Lim KM, Noh JY, Lee MY, Jung YS, Chung JH: Lysophosphatidic acid induces thrombogenic activity through phosphatidylserine exposure and procoagulant microvesicle generation in human erythrocytes. Arterioscler Thromb Vasc Biol 2007;27:414-421.

$\$ 98$ Zwaal RF, Comfurius P, Bevers EM: Surface exposure of phosphatidylserine in pathological cells. Cell Mol Life Sci 2005;62:971-988.

$\$ 99$ Hbibi M, Abourazzak S, Babakhouya A, Boubou M, Atmani S, Tizniti S, Bouharrou A: Severe hypernatremic dehydration associated with cerebral venous and aortic thrombosis in the neonatal period. BMJ Case Rep DOI: 10.1136/bcr.07.2011.4426.

100 Sackett DL: Possible risk factors in the development of venous thrombosis. Gastrointestinal disease, infection and dehydration. Milbank Mem Fund Q 1972;50:105-122.

101 Watson HG, Baglin TP: Guidelines on travel-related venous thrombosis. Br J Haematol 2011;152:31-34. 